\title{
The effect of ability and motivation on job satisfaction and employee performance
}

\author{
Rabiyatul Jasiyah \\ Assistant Professor, \\ Muhammadiyah University of Buton, \\ Southeast Sulawesi \\ H. Mansyur Ramli \\ Professor in Management, \\ Postgraduate School, \\ Moslem University of Indonesia, Makassar \\ H. Bahar Sinring \\ Professor in Management, \\ Postgraduate School, \\ Moslem University of Indonesia, Makassar \\ St. Sukmawati \\ Associate Professor, \\ Postgraduate School, \\ Moslem University of Indonesia, Makassar
}

\begin{abstract}
This study aims to analyze the influence of ability and partial motivation on job satisfaction and employee performance mediated by job satisfaction. This research was conducted at the Regional Office of Directorate General of Treasury, Ministry of Finance of Republic of Indonesia (DJPBN) Southeast Sulawesi. A sample of 220 employees and data were analyzed using confirmatory factor analyses with AMOS Ver. 22. The results of this study indicate that the ability and motivation partially have a direct effect on job satisfaction, ability and motivation partially have a direct effect on employee performance, and ability and motivation partially have a direct effect on employee performance through job satisfaction.
\end{abstract}

Keywords: Ability, motivation, job satisfaction, employee performance

\section{INTRODUCTION}

The implementation of good governance is one of the demands that are intensively carried out by the public to the government, in line with the increasingly advanced level of public knowledge, technological development, socio-economic conditions, and so on, besides the influence of globalization. These demands need to be responded to well by the government by making paradigm changes in realizing responsibility to the community. In order for the development of regional government to be realized in managing existing resources, a form of regional apparatus organization is needed so that the objectives of the regional government can be achieved.

The objectives of regional organizations will be achieved effectively and efficiently if the resources owned are managed properly. Resources that must be owned by the organization include of man, money, machine, materials, and markets. The four resources can be grouped 
into two resources, namely: human resources and non-human resources. The human resources are an asset for achieving the organizational goals. The human resource is a very key position of the organization today (Ivancevich, 2001). While non-human resources are organizational assets if human resources as employees have the ability to manage them, then human resources are absolutely present in every organization in any form and purpose to be achieved by the organization.

The research was carried out at the Southeast Sulawesi Provincial Directorate General of Treasury, Ministry of Finance of Republic of Indonesia (DJPBN). The Directorate General of Treasury has a vision of becoming a treasury manager in a region that is professional, modern, transparent and accountable. Based on Performance Target Unit (SKU) Treasury Service Office (KPPN) Southeast Sulawesi Province obtained the achievement of performance as follows:

Table 1. Target Unit Performance (SKU) KPPN Southeast Sulawesi province (Based on Year)

\begin{tabular}{|c|c|c|c|c|}
\hline \multirow[b]{2}{*}{ Performance } & \multicolumn{2}{|c|}{2016} & \multicolumn{2}{|c|}{2017} \\
\hline & Target (\%) & $\begin{array}{l}\text { Actual } \\
\text { (\%) }\end{array}$ & $\begin{array}{c}\text { Target } \\
(\%)\end{array}$ & $\begin{array}{l}\text { Realization } \\
\text { (\%) }\end{array}$ \\
\hline $\begin{array}{l}\text { Percentage of absorption of expenditures state in the } \\
\text { Budget Implementation (DIPA) Work Unit (Satker) }\end{array}$ & 95\%delivery & $95 \%$ & $100 \%$ & $95 \%$ \\
\hline Customer satisfaction index related to service & $\left.3^{*}\right)$ & $3^{*}$ & $\left.3^{*}\right)$ & $\left.3^{*}\right)$ \\
\hline $\begin{array}{l}\text { Percentage of a number of disbursement orders (SP2D) } \\
\text { issued on time }\end{array}$ & $100 \%$ & $95 \%$ & $100 \%$ & $90 \%$ \\
\hline $\begin{array}{l}\text { The level of stakeholder understanding of the treasury } \\
\text { field tasks }\end{array}$ & $90 \%$ & $80 \%$ & $100 \%$ & $85 \%$ \\
\hline Percentage of accuracy and timeliness & $90 \%$ & $80 \%$ & $100 \%$ & $80 \%$ \\
\hline $\begin{array}{l}\text { Level of employee compliance with employee discipline } \\
\text { rules }\end{array}$ & $100 \%$ & $90 \%$ & $100 \%$ & $90 \%$ \\
\hline $\begin{array}{l}\text { Percentage of number of employees participating in } \\
\text { training }\end{array}$ & $100 \%$ & $95 \%$ & $100 \%$ & $90 \%$ \\
\hline
\end{tabular}

*) Satisfied

Source: Regional Office of Directorate General of Treasury (DJPBN) Southeast Sulawesi Province, Ministry of Finance of the Republic of Indonesia (2018)

The phenomenon of the decline in employee performance indicates that employees have not optimally implemented their duties and functions according to the realization of the percentage of performance. Indications that are the cause of employee performance have decreased because the level of employee job satisfaction is not fulfilled, especially in carrying out the work itself, lack of ability and lack of motivation. Several previous empirical studies have shown that there is a positive and significant influence between work ability on performance (Widyaningrum, 2012; Priadana \& Riswandi, 2013).

Employee performance is a synergy of a number of factors, namely internal employee factors, organizational internal environmental factors and organizational external environmental factors in influencing employee work behavior which will then affect the performance of the employees concerned (Wirawan, 2009). Motivation is assumed to determine performance through the tendency of an individual's business allocation to carry out a job (Hailesilasie, 2009). Motivation of the work of employees as executors of an accounting system will determine the reliability of a financial report. Strong motivation will encourage employees to always try to complete each of their work properly so that it will affect the employee's performance well (Ikhsan \& Ishak, 2005). 


\section{Work ability}

\section{LITERATURE REVIEW}

Ability is a condition needed to support work motivation in determining employee performance (Hailesilasie, 2009; Sari \& Sjahruddin, 2018). Another scholar's view, states that work ability is a condition that exists in workers who are truly efficient and successful in working according to their field of work. In its formation, work ability refers to several indicators (Hersey \& Blanchard, 2008), such as technical abilities, conceptual abilities, social abilities. Several factors that must be possessed by human resources are: knowledge, imagination, practical knowledge, search skills, foresight and communication skills (Casson, 1982).

\section{Motivation}

Motivation is a desire found in an individual who stimulates an act (Sedarmayanti, 2009). In practice there are several motivational theories such as those proposed by Mangkunegara (2003), namely the theory of needs hierarchy from Abraham Maslow. Maslow's view of the movement of human relations focuses on the need as a key foundation. Maslow has identified five levels of human needs, namely physiological needs, security, social, self-esteem, and selfactualization. Maslow's theory rests on two main principles, namely: a) the principle of deficiencies, namely satisfied needs is not a behavioral motivator. b) The principle of forward motion, that is, five needs exist in the hierarchy which has the potential needs at several levels, which will only be moved immediately if the needs at the lower level are satisfied.

In addition to the hierarchy of needs theory, there is a motivation theory that is always used by scholars (Mangkunegara, 2003), namely the theory of Mc.Clelland's achievement motivation (Achievement Motivation Theory) which states that human resources in one organization have potential energy reserves. How energy is released and used depends on the strength of the motivation of a person and the situation and opportunities available. According to McLelland's Achievement Motivation Theory, there are three factors or dimensions of motivation, namely: motives, expectations, incentives. Theory of achievement motivation focuses on three needs, namely: the need for achievement, the need for affiliation, and the need for power.

Based on the process there are theories that are considered capable of covering the shortcomings of Maslow's hierarchy of needs, the theory is known as ERG Theory (Existence, Relatedness, and Growth) (Siagian, 2012). The ERG theory and Maslow's hierarchy of needs theory are content theories (motivation theory) which both state that human motivation is influenced by their needs. The difference between the ERG theory and Maslow's Hierarchy of Needs Theory is that a need does not have to be fulfilled before individuals can meet needs that are at a higher level. While according to Maslow, individuals will remain at a level of need until these needs are satisfied.

\section{Job satisfaction}

Job satisfaction is a feeling of supporting or not supporting someone experienced in work (Davis \& Newstrom, 1985). In its implementation there are several job satisfaction theories as proposed by Mangkunegara (2009), that: (1) equity theory from Adam said that there are four main components in this theory, namely input, outcome, comparison person, and equityinequity. (2) Difference theory (discrepancy theory) from Porter (1967) who argued that to measure job satisfaction can be done by comparing the things that should be with the perceived reality. (3) the need fulfillment theory from Schaffer (1991), which argues that job satisfaction will directly influence the extent to which individual needs can be truly satisfied. 
Other theories, namely (4) group view theory (social reference group theory) from Alderfer in Mangkunegara (2009) which states that one's job satisfaction is not dependent on meeting needs alone, but is highly dependent on group views and opinions, (5) a two-factor theory from Herzberg which states that there are two factors that can cause satisfaction or dissatisfaction, namely (a) maintenance factors (maintenance factors) and (b) motivational factors (motivational factors). Maintenance factors related to the nature of humans who want to obtain physical tranquility, which includes: (a) salary, technique and quality of supervision; (b) administration and policy of the institution; (c) the quality of interpersonal relationships among colleagues with superiors and with subordinates; (d) work security; (e) status; (f) additional benefits and (g) working conditions. (6) The appreciation theory was developed by Victor Vroom and later expanded again by Porter and Lawler, who explained that motivation is a product of the way someone wants something and allows certain actions to determine it.

\section{Employee performance}

Performance is an output produced by functions or indicators of a job or a profession in a certain time (Wirawan, 2009). Individual performance can be operationalized with intrapersonal factors which include ability and motivation. The ability of an employee is determined by the knowledge (skills) and skills (skills) they have. Motivation and personality are impulses formed by factors that come from within the employee itself and outside factors (Robbins, 2008). Performance is the result of a synergy of a number of factors which include: employee internal factors, organizational internal environmental factors, and organizational external environment factors (Wirawan, 2009).

Performance appraisal is the process through which an organization evaluates or evaluates employee performance. This activity can improve personnel decisions and provide feedback to employees about the implementation of work (Handoko, 2001). Employee performance has several indicators as follows: quantity, quality, efficiency, employee effort in completing work, employee standards, timeliness, ability and knowledge of employees related to the main work carried out; and the level of employee creativity (Mangkunegara, 2013).

\section{RESEARCH FRAMEWORK}

Statement of the relationship between variables is built based on relevant theories and results of previous studies. Theoretical reviews and empirical findings are used as the basis for describing the conceptual framework of the research and are used as the basis for reducing the research hypothesis. Ability is the certainty of an individual to do some tasks in a good job of intellectual ability, namely the ability needed to do mental activities, as well as physical abilities that are needed to perform tasks that require stamina, dexterity, strength, and skill. Someone who has good work ability has a relatively stable attitude and behavior character when facing a workplace situation that is formed from the synergy between character, concept, internal motivation, knowledge capacity so that he can quickly overcome problems that occur, do work with calm and full of confidence, looking at work as an obligation that must be done sincerely, openly and always improve the quality of self (Robbins, 2008).

The higher of the person ability has which is marked quickly in overcoming work problems, seeing work as an obligation that must be done sincerely and openly, improving self-quality which will psychologically provide meaningful work experience and a sense of personal responsibility for the results of his work and finally all of this will increase job satisfaction (Ainswotrh et al., 2002). Empirical evidence shows that ability has a direct effect on job satisfaction (Priadana \& Ruswandi, 2013). 
Motivation is the giving of driving force that creates the enthusiasm of one's work so that they will cooperate, work effectively and be integrated with all their efforts to achieve job satisfaction (Cohen, 1999; Toban \& Sjahruddin, 2016). Research by Furnham \& Eracleous (2009) concludes that motivation influences job satisfaction. Performance is a function of abilities (Hostager et al., 1998). The level of employee performance will depend on the ability factor of the employee itself such as the level of education, knowledge, experience where the higher level of ability will have higher performance (Robbins, 2008).

Empirical evidence shows that employee work ability influences employee performance. Motivation is the most important component of the overall performance of employees and has opened a new strategic window for the organization. There needs to be an identifier of a company's performance results from one that most influences employee motivation activities, and to determine where the situation of intrinsic rewards is more profitable and where extrinsic is more useful (Syardianto, 2014). One of the goals of motivating employees is to improve employee work productivity. This means that the higher the motivation of employees in work, the higher the productivity (Hasibuan, 2006).

Job satisfaction is a general attitude of an individual to his work. Work requires interaction with coworkers, supervisors, rules and organizational policies, performance standards, working conditions and so on. A person with a high level of job satisfaction shows a positive attitude towards work, whereas someone who is not satisfied with his job shows a negative attitude towards performance (Robbins \& Judge, 2015). There is a positive relationship between job satisfaction and performance and organizations whose human resources are more satisfied in work will tend to be more effective than those in organizations with less satisfied human resources (Ostroff, 1992). Based on the statement, it can be concluded that there is an influence of job satisfaction on employee performance (Engko, 2008).

Based on theoretical and empirical studies, previous research on the influence between variables that have been described, and the researchers built the model as a conceptual framework of research that empirically analyzed causality between the effect of ability, motivation, and job satisfaction and employee performance.

Based on theoretical and empirical studies and previous research we will analyze the hypothesis:

1) Ability and motivation partially have a significant positive direct effect on job satisfaction

2) Ability and motivation partially have a significant positive direct effect on job performance

3) Ability and motivation will have an indirect positive effect on job performance, the mediator effect of job satisfaction

\section{Descriptive variables}

\section{RESULTS}

The results of the average value in the variable description indicate that the perceptions of the employees are at a level that is satisfied with the indicators and constructs formed from the variables of ability, motivation, and job satisfaction and employee performance at the Regional Office of Directorate General of Treasury, Ministry of Finance of Republic of Indonesia (DJPBN) Southeast Sulawesi Province. 
Table 2. Descriptive

\begin{tabular}{cclc}
\hline Construction & Average value $(\boldsymbol{\mu})$ & \multicolumn{1}{c}{ Indicator } & Average value $(\boldsymbol{\mu})$ \\
\hline Ability $\left(\mathrm{X}_{1}\right)$ & 4.10 & Ability to empathize $\left(\mathrm{X}_{16}\right)$ & 4,16 \\
Motivation $\left(\mathrm{X}_{2}\right)$ & 4.07 & Affiliated Needs $\left(\mathrm{X}_{22}\right)$ & 4.15 \\
Job satisfaction $(\mathrm{Y})$ & 4.25 & Job Partner Satisfaction $\left(\mathrm{Y}_{12}\right)$ & 4.28 \\
Employee performance $(\mathrm{Z})$ & 4,10 & Quantity $\left(\mathrm{Z}_{2}\right)$ & 4.57 \\
\hline
\end{tabular}

\section{GOODNESS OF FIT}

Goodness of fit index shows whether the model formed is in accordance with the empirical data collected through the sample. The results of goodness of fit indicate that all criteria have met the value of cut off value so that the model formed is in accordance with the empirical data obtained.

Table 3. Goddness of fit index

\begin{tabular}{cccc}
\hline Goodness of fit & Cut-off value & model & Description \\
\hline Chi square (x2) & $201,423(0.05: 170)$ & 190,797 & Good \\
Probability 5 & 0.05 & 0,131 & Good \\
CMIN / DF & $\leq 2,00$ & 1,122 & Good \\
RMSEA & 80.08 & 0.024 & Good \\
GFI & 0.90 & 0.933 & Good \\
AGFI & $\geq 0.90$ & 0.891 & Good \\
TLI & $\geq 0.95$ & 0.991 & Good \\
CFI & $\geq 0.95$ & 0.994 & Good \\
\hline
\end{tabular}

\section{TESTING THE VALIDITY OF THE MEASUREMENT MODEL}

Test the validity of the measurement model aimed at knowing the correlation and real relationship between indicators for each construct. Indicators that have a strong and real relationship can be known through the value of loading factors and probability values (Ramli \& Sjahruddin, 2015). The value of loading factor shows the correlation coefficient $(r)$ of each indicator against the construct ( $\mathrm{r} 70.7$ ) and the probability value indicates a real relationship ( $P 5$ 0.05). The results of confirmatory factor analysis showed that collaboration ability $(\mathrm{r}=$ 0.791; $\mathrm{P} \leq$ 0.05), affiliated needs $(\mathrm{r}=0.658$; $\mathrm{P} 5$ 0.05), salary $(\mathrm{r}=0.916$; $\mathrm{P} 50.05)$; quality $(\mathrm{r}=$ 0.783; P 5 0.05), has a strong and real positive relationship with each construct.

\section{TESTING THE VALIDITY OF THE STRUCTURAL MODEL}

Test the validity of the structural model shows the relationship between the independent variables on the dependent variable.

Table 4. Hypothesis

\begin{tabular}{|c|c|c|c|c|c|c|c|}
\hline Exogenous & $\begin{array}{l}\text { Variable } \\
\text { Intervening }\end{array}$ & Endogenous & $\begin{array}{c}\text { P- } \\
\text { Value }\end{array}$ & $\begin{array}{l}\text { Direct } \\
\text { Effect }\end{array}$ & $\begin{array}{l}\text { Indirect } \\
\text { Effect }\end{array}$ & $\begin{array}{l}\text { Total } \\
\text { Effect }\end{array}$ & Results \\
\hline Ability (X1) & & Job satisfaction (Y) & 0.000 & 0.258 & - & 0.258 & $\begin{array}{l}\text { Significant } \\
\text { Positive }\end{array}$ \\
\hline Motivation (X2) & & Job satisfaction (Y) & 0.000 & 0.462 & - & 0.462 & $\begin{array}{l}\text { Significant } \\
\text { Positive }\end{array}$ \\
\hline Ability $\left(\mathrm{X}_{1}\right)$ & & $\begin{array}{l}\text { Employee } \\
\text { performance (Z) }\end{array}$ & 0.000 & 0.283 & - & 0.283 & $\begin{array}{l}\text { Positive } \\
\text { Significant }\end{array}$ \\
\hline Motivation $\left(\mathrm{X}_{2}\right)$ & & $\begin{array}{l}\text { Employee } \\
\text { performance }(\mathrm{Z})\end{array}$ & 0.000 & 0.379 & - & 0.379 & $\begin{array}{l}\text { Positive } \\
\text { Significant }\end{array}$ \\
\hline $\begin{array}{l}\text { Job satisfaction } \\
\text { (Y) }\end{array}$ & & $\begin{array}{l}\text { Employee } \\
\text { performance }(\mathrm{Z})\end{array}$ & 0.035 & 0.146 & - & 0.146 & $\begin{array}{l}\text { Positive } \\
\text { Significant }\end{array}$ \\
\hline Ability $\left(X_{1}\right)$ & $\begin{array}{l}\text { Job satisfaction } \\
\text { (Y) }\end{array}$ & $\begin{array}{l}\text { Employee } \\
\text { performance }(Z)\end{array}$ & 0.032 & 0.283 & 0.038 & 0.321 & $\begin{array}{l}\text { Positive } \\
\text { Significant }\end{array}$ \\
\hline Motivation $\left(\mathrm{X}_{2}\right)$ & $\begin{array}{l}\text { Job satisfaction } \\
(\mathrm{Y})\end{array}$ & $\begin{array}{l}\text { Employee } \\
\text { performance (Z) }\end{array}$ & 0.013 & 0.379 & 0.067 & 0.446 & $\begin{array}{l}\text { Positive } \\
\text { Significant } \\
\end{array}$ \\
\hline
\end{tabular}


Based on the results of hypothesis testing, it appears that the probability value $\leq 0.05$ and the direct and indirect effect values show a positive direction, so it can be concluded as follows:

1. Ability and motivation have partially a significant positive direct effect on employee job satisfaction at the Directorate General of State Treasury (DJPBN) of Southeast Sulawesi Province.

2. Southeast Sulawesi Province's Directorate General of State Treasury (DJPBN)

3. has a significant positive effect on employee performance through employee job satisfaction at the Sulawesi Provincial Directorate General of Treasury (DJPBN) Tenggara

\section{DISCUSSIONS}

\section{Effect of work ability on job satisfaction.}

Hypothesis test results from this study indicate that work ability has a positive and significant effect on job satisfaction. Work ability is related to the capacity possessed by an employee to do some tasks in a good job of intellectual ability, namely the ability needed to do mental activities, as well as physical, namely the ability needed to perform tasks that require stamina, dexterity, strength and skill (Robbins , 2008). Ability is one of the factors that influence job satisfaction (Robbins and Judge, 2015). Employees who have the ability to work will cause feelings of satisfaction. Job satisfaction is achieved when the work of an employee is in accordance with the interests and abilities of the employee itself (Robbins and Judge, 2015).

The findings of previous researchers indicate that work ability has a significant effect on job satisfaction (Soetrisno, 2011; Mardiana, 2018). Competence shown through knowledge, skills and abilities and personality characteristics can influence job satisfaction (Surya, 2003). The higher the ability a person has which is marked quickly in overcoming work problems, seeing work as an obligation that must be done sincerely and openly, improving self-quality which will psychologically provide meaningful work experience and a sense of personal responsibility for the results of his work and finally all of this will increase job satisfaction (Ainsworth et al., 2002). The inconsistency of findings provides new evidence that ability does not have a direct effect on satisfaction (Snow, 2016). The difference in research results shows that job satisfaction is not only influenced by the abilities possessed by an employee, but other factors that support job satisfaction such as salary, the job itself, co-worker promotion, and working conditions.

The confirmatory factor analysis shows that the ability to work together has an important role in increasing the ability of employees to work. The ability to cooperate is part of social ability. Cooperation in a group is a group of employees who have a common goal. Cooperation in a group has an important meaning where the presence of each employee has meaning and value for other employees, and is in a situation of mutual influence. Each employee in the group will get reciprocal actions and reactions so that group dynamics occur. Employees who feel that their existence is accepted in a group will create a feeling of satisfaction with their abilities.

The results of this study are in line with the statement by Mangkunegara (2009) that an employee will feel satisfaction if the work he does is in accordance with the interests and needs expected by his group. The results of this study are relevant to the fulfillment of needs theory proposed by Schaffer (Staw, 1991), that job satisfaction will directly influence the extent to which the needs of employees can be truly satisfied. One of the needs of employees according to Maslow's hierarchy of needs theory is social needs (Robbins \& Judge, 2015). 


\section{Effect of work motivation on job satisfaction}

The results of hypothesis testing from this study indicate that work motivation has a positive and significant effect on job satisfaction. Work motivation is a desire found in an employee who stimulates an action. Employees who have motivation to work have the power directed to regulate and provide a sense of satisfaction to meet their needs. The results of this study are in line with several previous empirical studies which showed that work motivation has a positive and significant effect on job satisfaction (Snow, 2016; Lusri \& Siagian, 2017).

Based on the results of research on confirmatory factor analysis indicates that affiliated needs have an important role to play in increasing motivation. Employees who have affiliated needs have the urge to interact with other employees, be with other employees, do not want to do something that is detrimental to other employees. The results of this study are in line with the needs for achievement theory pioneered by David McClelland (Hasibuan, 2006), that dividing human needs consists of the need for achievement, the need for affiliation and the need for power.

The findings of this study support the hierarchy of needs theory (Robbins \& Judge, 2015) which identifies five levels of human needs, namely physiological, security, social or affiliated needs, self-esteem, and self-actualization. This theory also emphasizes that satisfied needs are not behavioral motivators. Employees will act to satisfy lost needs so that lack of satisfaction will remain. Employees will continue to strive to meet higher needs if the needs at a lower level are satisfied. The hierarchy of needs theory implies that managers can help employees satisfy their important needs at work so as to create job satisfaction and achieve productivity.

\section{Effect of work ability on employee performance}

Hypothesis test results from this study indicate that work ability has a positive and significant effect on employee performance. Employee performance can be operationalized with intrapersonal factors which include ability and motivation. The ability of an employee is determined by the knowledge and skills they have. Motivation and personality are impulses formed by factors originating from within the employee itself as well as external factors; the statement is relevant to the statement by Setiawan \& Ghozali (2006) that performance is a function of ability and motivation.

The results of this study support the findings of previous researchers, that work ability has a positive and significant influence on employee performance (Yulius \& Susetyo, 2014; Samiun et al., 2017). Ability is a condition needed to support work motivation in determining employee performance (Hailesilasie, 2009). The results of this study are in line with the opinions expressed by Hasibuan (2006) which states that the results of work or performance achieved by an employee in carrying out tasks assigned to him are based on the skills, experience, abilities and motivation possessed by an employee.

\section{Effect of work motivation on employee performance}

Hypothesis test results from this study indicate that motivation has a positive and significant effect on employee performance. Motivation is a product of the way an employee wants something and allows certain actions to determine it. Employees who have high motivation will have a strong desire to improve their performance. This is relevant with Vroom's expectancy theory assumes that behavior results from conscious choices among alternatives whose purpose it is to maximize pleasure and to minimize pain. Vroom realized that an employee's performance is based on individual factors such as personality, skills, knowledge, experience and abilities (Davis \& Newstrom, 1997), those employees who have high motivation will want something and allow certain actions to determine it. Actions can be 
carried out by an employee by trying more through various trainings that have an impact on improving employee performance. Employees who have high motivation will have valence arising from internal employees who are conditioned by the experience they have.

The results of this study are in line with several previous studies, that there is a positive and significant influence between motivation on employee performance (Furnham et al., 2009; Aisha \& Hardjomidjojo, 2013; Onanda, 2015). This study supports the findings of other researchers that employees with high motivation will be passionate about work; it will be able to improve their performance (Beal \& Stevens, 2007). The results of this study are relevant with Luthans (2006), which is based on McClelland's motivation theory that the need for an employee's performance reflected through performance will lead to motivation from employees and they strive to meet those needs.

This study rejects the findings of other researchers, that motivation does not affect employee performance (Nicholls, 2017). This is due to the factors that support the formation of strong motivation are still lacking such as motives, expectations and incentives and motivation that is formed is not in accordance with needs. These findings are in line with Adam's justice theory (Robbins, 2008), which states that an employee will feel satisfied or dissatisfied depending on the justice he receives in certain situations. This means that motivation is formed depending on the extent to which employees feel the justice received.

\section{Effect of job satisfaction on employee performance}

Hypothesis test results from this study indicate that job satisfaction has a positive and significant effect on employee performance. Employees with high job satisfaction certainly have high morale, so the performance is more optimal. Organizational performance is strongly influenced by employee performance so that job satisfaction has an important role in supporting performance. Job satisfaction has a direct effect on performance levels. Job satisfaction is a tendency of attitudes and feelings of an employee towards the work that has been entrusted to him. Employees get job satisfaction if they show good attitudes and feelings, and vice versa employees do not get job satisfaction if they show a tendency toward bad attitudes and feelings. Good attitudes and feelings will support the improvement of employee performance (Luthans, 2006).

The results of this study support several previous studies which stated that there is a positive and significant influence between job satisfaction on employee performance (Brahmasari, \& Suprayetno, 2009). The results of this study are in line with intrapersonal comparison theory (Lawler \& Porter, 1967). This theory confirms satisfaction or dissatisfaction felt by employees is the result of a comparison of self-assessment. Porter and Lawler concluded that an individual's motivation to complete a task is affected by the reward they expect to receive for completing the task. However Porter and Lawler introduced additional aspects to the expectancy theory as they felt that Vroom's theory was too simple. Employees who have good performance but receive rewards that are not in line with their expectations will create dissatisfaction, which will affect performance.

\section{Effect of work ability on employee performance through job satisfaction}

The results of hypothesis testing from this study indicate that ability has a positive and significant influence on employee performance through job satisfaction. Employee performance basically depends on many factors including employee satisfaction (Malik et al., 2011). Employees who have good performance are strongly influenced by their abilities. This is in accordance with the opinion expressed by Hailesilasie (2009) which states that ability is a 
condition needed to support work motivation in determining employee performance. The results of this study support the findings, that the employees will feel satisfaction if supported by their abilities so that it has an impact on employee performance (Hasanuddin \& Sjahruddin, 2017; Mardiana, 2018).

\section{Effect of motivation on employee performance through job satisfaction}

The results of hypothesis testing from this study indicate that motivation has a positive and significant influence on employee performance through job satisfaction. Job satisfaction reflects an employee's feelings for his job. Job satisfaction is a function of needs. Employees who feel their needs can be fulfilled will create feelings of satisfaction with their work and have an impact on employee performance (Mathis \& Jackson, 2000).

Performance is a function of ability and motivation (Setiawan \& Ghozali, 2006). Individual performance can be operationalized by intra-personal factors which include ability and motivation (Robbins, 2008; in Hailesilasie, 2009). The internal factors of employees synergize with the internal and external environmental factors of the organization then influence work behavior. This work behavior is related to work motivation. This work behavior further influences employee performance. The better work behavior (for example, the higher the employee's motivation), the better the performance will be. While that behavior is getting better together (Wirawan, 2009).

\section{References}

Ainsworth, M., Smith, N., \& Millership, A. (2002). Managing performance, managing people: understanding and improving team performance. Longman Publishing Group.

Aisha, AN, \& Hardjomidjojo, P. (2013). Effects of working abilities, working conditions, motivation and incentive on employees, multi-dimensional performance. International Journal of Innovation, Management and Technology, $4(6), 605$.

Beal, CR, \& Stevens, RH (2007). Student motivation and performance in scientific problem solving simulations. In Proceedings of the 2007 conference on Artificial Intelligence in Education: Building Technology Rich Learning Context That Work (pp. 539-541). IOS Press.

Brahmasari, IA, \& Suprayetno, A. (2009). Effect of work motivation, leadership and organizational culture on employee job satisfaction and its impact on company performance (Case study at PT. Pei Hai International Wiratama Indonesia). Management and entrepreneurship journal, 10 (2), 124-135.

Casson, M. (1982). The entrepreneur: An economic theory. Rowman \& Littlefield.

Cohen, JL (1999). Changing the paradigm of Citizenship and the Exclusiveness of the Demos. International sociology, 14 (3), 245-268.

Davis, Keith \& John W. Newstrom. 1985. Behavior in Organizations. Jakarta. Erlangga

Engko, C. (2008). Effect of job satisfaction on individual performance with self-esteem and self-efficacy as intervening variables. Business and accounting journals, 10 (1), 1-12.

Furnham, A., Eracleous, A., \& Chamorro-Premuzic, T. (2009). Personality, motivation and job satisfaction: Hertzberg meets the Big Five. Journal of managerial psychology, 24 (8), 765-779.

https://doi.org/10.1108/02683940910996789

Hailesilasie, G. (2009). Determinants of public employees performance: evidence from Ethiopian public organizations. International Journal of Productivity and Performance Management, 58 (3), 238-253.

Handoko, T. Hani. (2001). Personnel Management and Human Resources. Yogyakarta: BPFE Yogyakarta

Hasanuddin, R., \& Sjahruddin, H. (2017). The Structure of Emotional Intelligence, Spiritual Intelligence and Its Relationship with Work Enthusiasm and Auditor Performance. World Journal of Business and Management, 3(1), 67. http://dx.doi.org/10.5296/wjbm.v3i1.11321

Hasibuan, Malayu SP (2006). Basic Management, Understanding, and Problems, Edition. Revision, Bumi Aksara: Jakarta. 
Hersey, Paul \& Blanchard, Kenneth H. (2004) Management of Organizational Behavior: Utilization of Human Resources, Translator Agus Dharma Erlangga, Jakarta

Hostager, TJ, Neil, TC, Decker, RL, \& Lorentz, RD (1998). Seeing environmental opportunities: effects of intrapreneurial abilities, efficacy, motivation and desirability. Journal of Organizational Change Management, 11 (1), 11-25. https://doi.org/10.1108/09534819810369536

Ikhsan, Arfan \& Ishak, Muhammad. (2005). Behavioral Accounting. Salemba Empat. Jakarta

Ivancevich, Jhon M. (2001). Human resource management Edition; 8 th, Boston; McGraw - Hill.

Lawler III, EE, \& Porter, LW (1967). The effect of performance on job satisfaction. Industrial relations: A journal of Economy and Society, 7 (1), 20-28. https://doi.org/10.1111/j.1468-232X.1967.tb01060.x

Lusri, L \& Siagian, H. (2017). Effect of Work Motivation on Employee Performance through Job Satisfaction as a Mediation Variable in Employees of PT. Borwita Citra Prima Surabaya. Agora, 5 (1).

Luthans, Fred. (2006). Organizational behavior. 10Edition, PT. Andi: Yogyakarta.

Malik, ME, Ghafoor, MM, \& Naseer, S. (2011). Organizational effectiveness: A case study of the telecommunication and banking sector of Pakistan. Far east journal of psychology and business, 2 (1), 37-48.

Mangkunegara, AA Anwar Prabu. (2003). Source Planning and Development. Human Power. Bandung. Refika Aditama

Mangkunegara, AA. Anwar Prabu. (2013), Human Resource Management. Company, Youth Rosdakarya, Bandung Mangkunegara. AA Anwar Prabu. (2009). Human Resource Management. Bandung: PT. Teenager Rosdakarya

Mardiana Yusuf, R. (2018). The effect of employee ability, ethic's hospital and leadership on job satisfaction through employee commitment: A study on Indonesian Type A government hospital. Journal of Management Development, 37 (1), 40-52. https://doi.org/10.1108/JMD-12-2016-0311

Mathis, Robert.L \& Jackson, John H. (2000). Human Resource Management. Jakarta: Salemba Empat.

Nicholls, JG (2017). Conceptions of ability and achievement motivation: A theory and its implications for education. In Learning and motivation in the classroom (pp. 211-238). Routledge.

Onanda, B. (2015). The Effects of Motivation on Job Performance of A Case Study of KCB Coast Region. International Journal of Scientific and Research. Publications, 5 (9).

Ostroff, C. (1992). Relationships between satisfaction, attitudes, and performance: An organizational level analysis. Journal of applied psychology, 77 (6), 963.

Priadana, S., \& Riswandi, I. (2013). The Effect of Work Ability and Motivation on Job Satisfaction and Its Implications on the Performance of the Mining and Energy Service of West Java Province. Journal of Economics, Business \& Entrepreneurship, 7 (2), 52-63.

Ramli, AH, \& Sjahruddin, H. (2015). Building patient loyalty in healthcare services. International Review of Management and Business Research, 4 (2), 391.

Robbins, P. Stephen. (2008). Organizational Behavior, Tenth Edition, language transfer Drs. Benjamin Molan. Salemba Empat: Jakarta.

Robbins, SP \& Timothy A. Judge. (2015). Organizational Behavior, Issue 16, Salemba Empat, Jakarta

Salju \& Zainuddin, Rahman. (2016). Effect of Ability, Motivation and Personality of Satisfaction and Performance Lecturer in Palopo. International Journal of Business and Management Invention. 14-16

Samiun, B., Sjahruddin, H., \& Purnomo, SH (2017). Effect of Empowerment on Employee Job Satisfaction.

Sari, RN, \& Sjahruddin, H. (2018). Effect of Competence on Performance Moderated Employee Professionalism.

Sedarmayanti. (2009). Human Resources and Work Productivity. Bandung. CV. Mandar Maju

Setiawan, IA, \& Ghozali, I. (2006). Behavioral Accounting: Concepts and Empirical Studies of Behavior of Accountants. Semarang: Diponegoro University Publishing Agency.

Siagian. Sondang P. (2012). Human Resource Management, Earth Literacy. Jakarta.

Soetrisno, USA (2011). Effect of Ability and Motivation on Employee Satisfaction and Performance at Sharia Banks in Jember Regency. 
Staw, BM (1991). Organization dressings When psychological theories can explain organizational action. Journal of Management, 17 (4), 805-819.

Surya, Dharma. (2003). Development of Human Resource Competence. Yogyakarta. Student Library.

Syardianto, D. Irawan. (2014). The Effect of Work Ability and Work Motivation on the Performance of Employees at the Transportation and Information Service Office of East Kutai Regency. Administrative Reform Journal, 885897.

Toban, C., \& Sjahruddin, H. (2016). The antecedent and consequence of Organizational Commitment and Job Satisfaction. Journal of Business and Management Sciences, 4 (2), 26-33. https://doi.org/10.12691/jbms-4-2-1

Widyaningrum, ME (2012). Effects Of Organizational Culture and Ability On Organizational Commitment And Performance In Ibnu Sina Hospital Gresik. Academic Research International, 2 (1), 349-355.

Wirawan. (2009). Performance Evaluation of Human Resource Management, Jakarta. Salemba Empat.

Yulius, S., \& Susetyo, S. (2014). Effect of Ability and Motivation on the Performance of Employees of the Secretariat Section at the Bengkulu Provincial Public Works Office (Doctoral dissertation, University of Bengkulu). 